\title{
Upper Gastrointestinal Bleeding in Critically III Patient: Literature Review
}

\author{
William Faisal , Luciana Rotty ${ }^{* *}$ \\ *Department of Internal Medicine, Faculty of Medicine, Universitas Sam Ratulangi/Prof. dr. R. D. \\ Kandou Hospital, Manado \\ ${ }^{* *}$ Division of Gastroentero-hepatology, Department of Internal Medicine \\ Faculty of Medicine, Universitas Sam Ratulangi/Prof. dr. R. D. Kandou Hospital, Manado
}

\section{Corresponding author:}

William Faisal. Department of Internal Medicine, Faculty of Medicine, Universitas Sam Ratulangi/Prof. dr. R. D. Kandou Hospital. Jl. Raya Tanawangko No. 56 Manado Indonesia. Phone/facsimile: +62-431-7283949. E-mail:williamfaisal289@gmail.com

\begin{abstract}
Critically ill patients are at risk for stress ulcers in the upper digestive tract. Various risk factors have been associated with this condition. Patients who are critically ill are at risk of bleeding due to stress related mucosal disease (SRMD). Upper gastrointestinal tract problems usually occur as a result of severe physiological stress. Patients may develop gastric erosion and develop stress ulcers with severe gastrointestinal bleeding which can be fatal. Routine pharmacological use of stress ulcer prophylaxis (SUP) does not reduce overall mortality in intensive care patients. This increases the risk of infectious complications, particularly nosocomial pneumonia and Clostridium difficile-associated diarrhea. Early enteral nutrition has been shown to be effective in preventing stress ulceration of the upper gastrointestinal tract in critically ill patients. Routine use of stress ulcer prophylaxis in all critically ill patients may be dangerous and does not appear to be cost-effective. SUP administration must follow an algorithm that clearly balances risks and benefits.
\end{abstract}

Keywords: gastrointestinal, bleeding, stress ulcer, intensive care unit, prophylaxis

\section{ABSTRAK}

Pasien yang sakit kritis berisiko mengalami ulkus stres pada saluran pencernaan bagian atas. Berbagai faktor risiko telah dikaitkan dengan kondisi ini. Pasien yang sakit kritis berisiko mengalami perdarahan akibat penyakit mukosa terkait stres. Masalah saluran cerna bagian atas biasanya terjadi akibat stres fisiologis yang berat. Pasien dapat mengalami erosi lambung dan mengalami ulkus stres dengan perdarahan gastrointestinal berat yang dapat berakibat fatal. Penggunaan farmakologis rutin dari profilaksis ulkus stress tidak mengurangi kematian secara keseluruhan pada pasien di ruang perawatan intensif. Hal ini meningkatkan risiko komplikasi infeksi, terutama pneumonia nosokomial dan diare terkait Clostridium difficile. Nutrisi enteral dini telah terbukti efektif dalam mencegah ulkus stres pada saluran cerna bagian atas pada pasien yang sakit kritis. Penggunaan profilaksis ulkus stres secara rutin pada semua pasien yang sakit kritis mungkin berbahaya dan tampaknya tidak hemat biaya. Administrasi profilaksis ulkus stress harus mengikuti algoritma yang secara jelas menyeimbangkan risiko dan manfaat.

Kata kunci: gastrointestinal, perdarahan, ulkus stres, unit perawatan intensif, profilaksis 


\section{INTRODUCTION}

Critically ill patients are at risk for stress ulcers in the upper digestive tract. Various risk factors have been associated with this condition. Stress ulcers associated with gastrointestinal bleeding were first described in $1969 .{ }^{1}$ Patients who are critically ill are at risk of bleeding due to stress related mucosal disease (SRMD). ${ }^{2}$ Upper gastrointestinal tract problems usually occur as a result of severe physiological stress. ${ }^{3}$ Patients may experience gastric erosion and develop into stress ulcer with severe gastrointestinal bleeding and can be fatal. ${ }^{4}$

Upper gastrointestinal tract bleeding (esophagus, stomach, or duodenum) when it is the cause of hospital admission is defined as primary and when it complicates hospitalization for patients who have been admitted for other reasons is defined as secondary. ${ }^{5}$ The reported incidence of stress-related mucosal damage varies from $6 \%$ to $100 \%$ in critically ill patients. ${ }^{6}$

Stress ulcers usually occur in the fundus and body of the stomach, but sometimes develop in the antrum, duodenum, or distal esophagus. The injury is usually superficial and causes blood to leak from the superficial capillaries. Deeper lesions may also occur, which can erode into the submucosa and cause massive bleeding or perforation. ${ }^{7}$

Based on current evidence and guidelines, routine acid-suppressing therapy to prevent stress ulcers is of no benefit in inpatients outside the intensive care setting. Only critically ill patients who meet specific criteria require acid-suppressing therapy. ${ }^{8}$ Routine use of pharmacological stress ulcer prophylaxis (SUP) has not reduced overall mortality in intensive care patients. ${ }^{9}$ Today polypharmacy is becoming more prevalent with advances in pharmaceutical science and development newer medications, though not necessarily better. ${ }^{10}$ Utilizing medical checklists can reduces mortality, the length of stay patients are treated, and improves quality of care. ${ }^{11}$ This literature review was created because many critically ill patients experience upper gastrointestinal bleeding and given SUP while being treated in the intensive care room.

\section{TYPES OF BLEEDING}

There are various types of bleeding that can occur in the upper gastrointestinal tract, such as occult bleeding, overt bleeding and clinically important bleeding (CIB). Several definitions have been used to describe various forms of stress ulcer bleeding. Occult bleeding is usually defined as a positive guaiac test on a stool sample without overt gastrointestinal bleeding. ${ }^{1}$
Significant bleeding is defined as hematemesis, coffeecolored emesis, melena, or nasogastric tube aspiration that bleeds. ${ }^{1,12}$ Clinically important bleeding is usually defined as real bleeding and any of the following 4 features: a spontaneous decrease in systolic or diastolic blood pressure of $20 \mathrm{mmHg}$ or more in 24 hours after upper gastrointestinal bleeding, an increase in orthostatic pulse rate by 20 beats per minute and a decrease in systolic blood pressure by $10 \mathrm{mmHg}$, a decrease in hemoglobin of at least $2 \mathrm{~g} / \mathrm{dL}(20 \mathrm{~g} / \mathrm{L})$ within 24 hours or requires transfusion of 2 units of red blood cells within 24 hours of bleeding. ${ }^{1,13,14}$

Stress related mucosal bleeding (SRMD) is a broad term used to describe a spectrum of pathologies associated with acute conditions, erosions, and upper gastrointestinal inflammation associated with critical illness. This is a continuum of asymptomatic superficial lesions discovered incidentally at endoscopy. Concealed gastrointestinal bleeding can cause anemia, real gastrointestinal bleeding and clinically significant gastrointestinal bleeding. ${ }^{12}$

\section{EPIDEMIOLOGY}

Stress ulcers were first described in 1969 when focal lesions in the mucosal fundus of the stomach were reported on post mortem examination in 7 (out of 150) critically ill patients. ${ }^{12}$ Since then endoscopic studies have identified that $74-100 \%$ of critically ill patients have mucosal erosions and subepithelial hemorrhage. stress-related within 24 hours after admission to the intensive care unit. ${ }^{1,12}$ These lesions are generally superficial and asymptomatic, but can extend to the submucosa and muscularis propria and cause erosion of the larger vessels openly and cause clinically significant bleeding. Endoscopy performed within 72 hours of disease onset have shown that $75-100 \%$ of critically ill patients exhibit severe gastric lesions. ${ }^{2}$

Clinically overt bleeding (hematemesis or positive nasogastric lavage for bright red blood) occurs in approximately $5-25 \%$ of critically ill patients who do not receive prophylactic therapy. ${ }^{1,6,12,15}$ The incidence of occult bleeding ranges from $15 \%$ to $50 \% .{ }^{1}$ Clinically overt hemorrhage did not predict clinically significant bleeding (defined as bleeding associated with hypotension, tachycardia, and decreased hemoglobin level requiring transfusion). It has been reported that about $20 \%$ of clinically significant bleeding has been proved clinically. ${ }^{6}$ The incidence of clinically significant gastrointestinal bleeding is now estimated to be $3 \%$ to $4 \% .^{1,6,12,15}$ The mortality in these patients is significantly higher when compared to patients who do not experience bleeding. ( $48.5 \%$ vs. $9.1 \%){ }^{1}$ 


\section{RISK FACTORS}

A large prospective cohort study involving critically ill patients showed upper gastrointestinal bleeding occur if these patients had the following risks: respiratory failure requiring mechanical ventilation for at least 48 hours and coagulopathy (platelet count less than 50,000 per cubic millimeter, international normalized ratio (INR) more than 1.5, or an activated partial thromboplastin time (APTT) more than 2 times the upper limit of normal is the only factor associated with an increased risk of CIB.${ }^{1,2}$ Coagulopathy include an iatrogenically induced state with anticoagulants. ${ }^{16}$ Cook et al identify the two risk factors with the odds ratio (OR) of 15.6 and 4,3 respectively. ${ }^{2}$

Other risk factors include severe sepsis, shock, liver failure, kidney failure, burns of $35 \%$ of the total body surface, organ transplantation, head trauma, spinal cord trauma, history of gastric ulcer disease, history of upper gastrointestinal bleeding, surgeries lasting more than 4 hours, high dose corticosteroids, nasogastric tube placement for more than 5 days, history of alcohol abuse, positive Helicobacter pylori serology, acute lung injury. ${ }^{1,4,8,13}$

\section{PATOPHYSIOLOGY}

In a healthy state, neurohormonal influences on parietal cells stimulate hydrochloric acid secretion, resulting in a $\mathrm{pH}$ of about 2 . Although this $\mathrm{pH}$ level will rapidly destroy most tissue, prostaglandins and nitric oxide help maintain the protective mucosal layer that protects the gastric epithelium. ${ }^{5}$ A layer of mucus protects the surface epithelium from hydrogen ions and other harmful substances present in the lumen of the intestine. This mucus layer also captures bicarbonate ions secreted by the mucosa to neutralize hydrogen ions. ${ }^{3}$ Bicarbonate diffuses into mucus layer to protect cell surface from damage by acids and proteolytic enzyme pepsin.$^{3,17}$ Acid sensors monitor extracellular $\mathrm{pH}$ which can potentially lead to decreased gastrin production so acid output is reduced. ${ }^{5}$

Defense mechanisms allow gastric mucosa to withstand exposure to damaging factors. ${ }^{6}$ Including local mechanisms such as mucus, bicarbonate, phospholipid barrier, continuous cell renewal of mucosal progenitor cells, alkaline currents, mucosal microcirculation, trefoil family factor peptide, heat shock proteins (HSP). ${ }^{2,6}$ These concepts are reviewed and illustrated by Laine and colleagues. Figure 1 illustrates the major components of gastric mucosal defense. Various peptides, including gastrin, cholecystokinin, thyrotropin-releasing hormone, bombesin, corticotropin releasing factor (CRF), epidermal growth factor (EGF), YY peptide, neurokinin A analogues, and intragastric peptone, attempt gastroprotection, which is eliminated by denervation of afferent nerves, blockade peptide receptor linked calcitonin gene, and inhibition of NO synthase. ${ }^{6}$

Stress-related gastric mucosal injury appears to be associated with local ischemia that progresses to significant mucosal injury requiring acid. Critically ill patients who received acute gastric mucosal lesions showed a significant reduction in gastric mucosal blood volume compared to controls. Significant gastric mucosal lesions occur only after blood pressure falls and causes mucosal blood flow reduced below $40 \%$ of the baseline value. In the absence of acid, gastric lesions were minimal, involving $4 \%$ of the corpus and $3 \%$ of the antrum. Intragastric acid $(0.1 \mathrm{~mol} \mathrm{~L}$ $\mathrm{HCl})$ gradually increased the lesion significantly to $53 \%$ and $45 \%$ of the surface of corpus and antrum. Studies suggest that splanchnic hypoperfusion with presence of gastric acid causes mucosal damage associated with stress and suppression of gastric acid will minimize injury. This forms the basis for using gastric antisecretory agents as prophylactic agents for stress-related mucosal injury. ${ }^{6}$ Mucus production decreased in poor perfusion caused by shock, sepsis, or trauma. ${ }^{6,7}$

Under hypoxia-ischemic conditions, reactive oxygen species (ROS), are produced rapidly and continuously. Oxidative stress due to hypoxia and ischemia of gastric and duodenal mucosa causes epithelial necrosis and mucosal ulceration resulting in cell death. ROS is known as a second messenger to regulate the expression of various pro-inflammatory genes leading to elaboration of chemical and humoral mediators of tissue inflammation and injury. ${ }^{6}$

The cyclooxygenase-2 (COX-2) pathway is rapidly induced in a pro ulcerogenic state and contributes to mucosal defense by minimizing injury. Ischemia/ reperfusion has been shown to increase messenger COX-2 RNA. Expression of COX-2 is assumed to be one of the mechanisms of protective expression when the stomach is stressed, and it contributes to mucosal defense by minimizing injury. COX-2 can prevent gastric mucosal ulcers. It is understood why exposure to non-steroidal anti-inflammatory drugs (NSAIDs) in critically ill patients may have severe side effects in maintaining the COX-2 defense mechanism. ${ }^{6}$

Reduced formation of nitric oxide (NO), a local mucosal vasodilator and increased levels of 


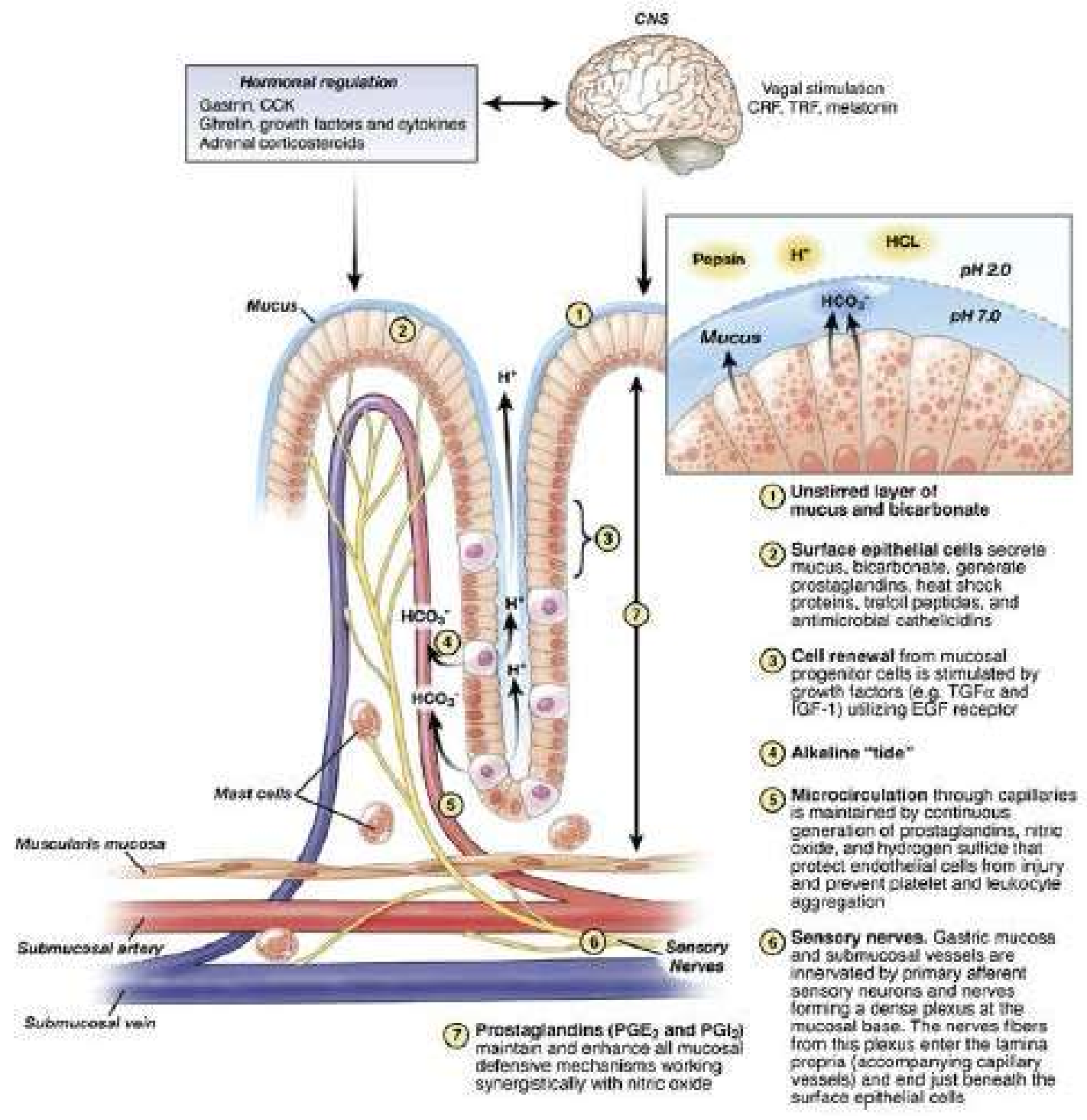

Figure 1. Gastric mucus defense

endothelin-1 (ET-1), a potent vasoconstrictor, appear to be involved in the events associated with impaired mucosal blood flow observed in SRMD. ${ }^{6,18}$ Under stress conditions, NO is produced by inducible nitrite oxide synthase (iNOS) reacts with $\mathrm{O} 2$ produced by neutrophils to form peroxynitrites. Inducible NO synthase can be pro-ulcerogenic during ischemia/ reperfusion. Levels of endothelin-1 in plasma and wounded mucosa in critically ill patients were found to be elevated, suggesting that endogenous ET-1 may play an important role in the local pathogenesis of stress ulcers. ${ }^{6}$

Critically ill patients experience decreased gastric mucosal blood flow through systemic hypotension and splanchnic hypoperfusion. Splanchnic hypoperfusion in mechanically ventilated patients is due to decreased cardiac output, release of pro-inflammatory cytokines, and activation of the sympathetic system. ${ }^{6}$ Splanchnic hypoperfusion (or gastric mucosal ischemia) is considered to be the main cause of SRMD in critically ill patients. Setting of the stomach pH very low in the intraluminal can lead to decreasing gastric blood flow, when combine with hypoperfusion and acidosis. Decreased gastric blood flow coupled with a low intraluminal gastric $\mathrm{pH}$ may be a major factor in stressrelated mucosal bleeding disease. ${ }^{3}$

Prostaglandins stimulate mucosal blood flow, mucus and bicarbonate production, thereby promoting growth and repair of epithelial cells. Bicarbonate mucosal barrier forms a physical barrier against the entry of luminal acids and pepsin, and is also important to bind diffused bicarbonate anions from gastric epithelial cells. ${ }^{13,19}$ Bicarbonate is strong enough to neutralize the $\mathrm{pH}$ in mucus on the surface of epithelial cells despite luminal $\mathrm{pH}$ of 1.5-2.0 . Gastric epithelial cell restitution (or re-epithelialization) is a defensive mechanism in which the rapid migration of energydependent epithelial cells occurs to areas of superficial 
damage, leading to restoration of epithelial integrity. Production of oxygen free radicals and physiological stress has been implicated in reducing the rate of cell proliferation and recovery of gastric epithelium. ${ }^{13}$

Gastric mucosal perfusion decreases early during critical illness due to number of factors: activation of sympathetic nervous system; increased catecholamine release and vasoconstriction, especially in the gastrointestinal tract; hypovolemia; decreased cardiac output; release of proinflammatory cytokines; and disruption of nitric oxide production (Figure 2). A decrease in microcirculation in gastrointestinal tract is more likely to observed in patients with sepsis. ${ }^{13}$ As consequence of splanchnic hypoperfusion, gastrointestinal motility decreases, slows the removal of acid and other irritants from the stomach, prolongs exposure to gastric acid and results in an increased risk of ulceration. Epithelial cell restitution leads to increased $\mathrm{H}+$ reverse diffusion and disruption of the barrier epithelium. This resulted in trauma to the gastric mucosa. $^{2}$

When blood flow is restored after prolonged hypoperfusion, elevated levels of nitric oxide synthase lead to hyperemia, cell death, and increased inflammatory response. This results in further gastrointestinal epithelial cell damage and ulcers. ${ }^{13}$ Common endoscopic findings range from superficial erosions to deep focal ulcers that penetrate submucosa, generally occur between the third and seventh day after being in the intensive care unit. ${ }^{4}$

Although the mechanisms described above can cause mucosal damage, they are often not sufficient by themselves to cause major ulceration and gastric bleeding. An essential component for real damage is the presence of stomach acid. Without acid, mucosal damage is minimal. This provides a rationale for using of acid-suppressing drugs such as PPIs or H2RA for pharmacological prophylaxis. ${ }^{9}$ Clinical trials have shown clearly that maintaining an intragastric $\mathrm{pH}$ above 3.5 to 5.0 can prevent injury. Maintaining a $\mathrm{pH}$ greater than 4 renders pepsin inactive and inhibits fibrinolysis. ${ }^{3}$

\section{MANAGEMENT}

\section{Pharmacology}

Overall management of critically ill patients, including focus on aggressive initial resuscitation, improved mucosal hypoperfusion, and the importance of early enteral nutrition. ${ }^{12}$ Because hypoperfusion appears to be an important factor in the development of SRMD, high-risk patients should be monitored and treated aggressively. Gastrotoxic agents such as NSAIDs or aspirin should be avoided. Measures should be taken to correct the state of the hemodynamic parameters to limit the use of vasopressors if possible, as these agents can exacerbate gastrointestinal tract ischemia. Vasopressors do raise blood pressure, but at the expense of mesenteric perfusion. Early enteral nutrition must be considered. Red blood cell transfusions may be required to maintain hemoglobin at adequate levels. Acid suppression therapy should

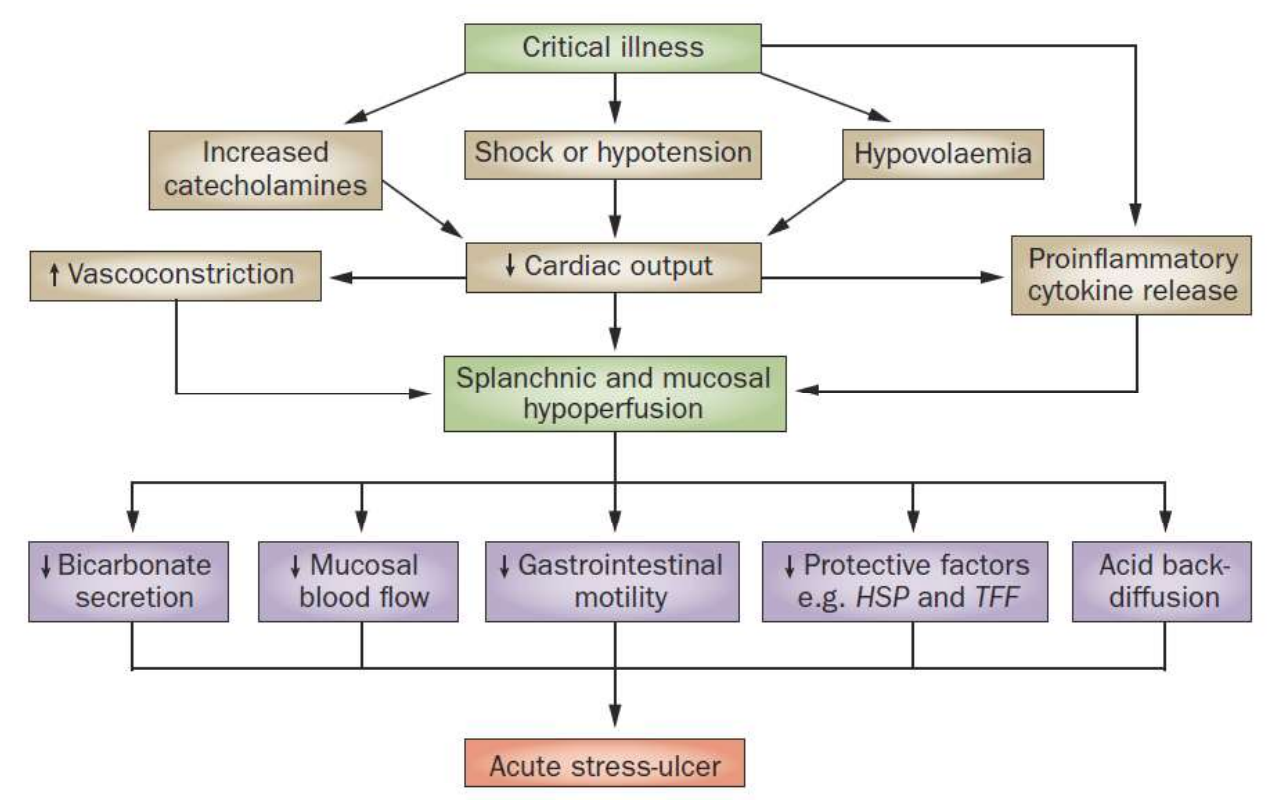

Figure 2. Patophysiology of stress ulcer bleeding 
be started. PPIs are the agent of choice because they have been shown to be more potent and reduce risk of rebleeding, and the need for surgical intervention for non-variceal gastroinestinal bleeding. ${ }^{6}$ Available data suggest that high-risk patients, such as those with coagulopathy, shock, or respiratory failure requiring mechanical ventilation, have a beneficial effect of prophylaxis against stress ulcers. ${ }^{20}$

The indiscriminate use of SUP in all critically treated patients is not recommended and may be dangerous for the patient. Risk of bleeding must be considered in every patient and using prophylaxis may not be suitable for those at low risk. Risk of gastrointestinal bleeding appears to be highest in patients who are mechanically ventilated or with coagulopathy. In the absence of these risk factors, presence of kidney failure, liver failure, hypotension, sepsis, or other risk factors can justify this intervention. ${ }^{1}$

Gastric antisecretory agents have been shown to substantially reduce the incidence of upper gastrointestinal bleeding due to secondary stress ulceration in critically ill high-risk patients. Some drugs that can be given as SUP are antacids, sucralfate, misoprostol, histamine- 2 receptor antagonists, and proton pump inhibitors (PPIs). ${ }^{6}$ Ulcers can be heal by neutralizing stomach acid and deactivating the proteolytic activity of pepsin using antacids contain magnesium and aluminum hydroxide..$^{13}$

Sucralfate forms a barrier on mucosal surface of stomach; stimulates mucus and bicarbonate secretion; stimulates growth factors and epidermal renewal; increase gastric mucosal blood flow and increase the release of prostaglandins. ${ }^{6,13}$ Sucralfate acts by adhering to epithelial cells that form a physical cytoprotective barrier in ulcers, thereby protecting gastric mucosa from the effects of acids and pepsin. ${ }^{6,12}$ Misoprostol is a synthetic PGE1 analogue with cytoprotective function of stomach and is antisecretory when given at high doses. ${ }^{6}$

Histamine2-receptor blockers (H2RB) competitively inhibit binding of histamine to $G$ protein receptors on the basolateral membrane of gastric parietal cells, resulting in decreased gastric acid production and decreased overall secretion. ${ }^{7,12,13}$ Proton pump inhibitors block acid secretion by binding and inhibiting the ATP-ase hydrogen-potassium pump which resides on luminal surface of parietal cell membrane and thereby increases the $\mathrm{pH}$ of the stomach. ${ }^{7,12}$

The optimal dose is still unknown but many physicians are choosing to use a high-dose intravenous PPI infusion of $80 \mathrm{mg}$ bolus followed by $8 \mathrm{mg} /$ hour infusion for 72 hours, because the highest quality evidence comes from trials using this regimen., ${ }^{2,21}$ Drug of choice class remains difficult, evidence supports the use of PPIs from H2RA to reduce the incidence of bleeding, without evidence of an increased risk of nosocomial pneumonia and no difference in mortality rates. The join guidelines from the American College of Cardiology, American Heart Association, and American College of Gastroenterology recommend PPI therapy for those taking clopidogrel with a high risk of bleeding. ${ }^{1}$

Cook et al conducted a meta-analysis of 10 randomized clinical trials (RCTs) comparing H2RA therapy with placebo: H2RA therapy was superior to placebo in reducing the risk of clinically important bleeding (CIB) $(\mathrm{OR}=0.44 ;$ 95\% CI: 0.22-0.88). A large multicentre study comparing sucralfate with ranitidine in 1200 patients on a ventilator, found a lower risk of CIB for ranitidine $(1.7 \%$ vs. $3.8 \%$; RR $=0.44 ; 95 \%$ CI: $0.21-0.92 ; p=0.02)$. The overall incidence of CIB was lower in PPI recipient group when compared to $\mathrm{H} 2 \mathrm{RA}$ group, $3.5 \%$ and $8 \%$, respectively $(\mathrm{OR}=0.42$; 95\% CI: 0.20-0.91). A more recent meta-analysis found that PPIs were more effective in preventing CIB (RR $=0.36$; 95\% CI: 0.19-0.67). ${ }^{1}$

\section{Non Pharmacology}

More aggressive therapy is indicated if prophylactic therapy fails and clinically significant stress-related gastrointestinal bleeding continues, esophagogastroduodenoscopy (EGD) is the main diagnostic procedure. An EGD can accurately identify the site of bleeding, provide prognostic information about the risk of rebleeding, and offer therapeutic potential. ${ }^{6}$

Early administration of enteral nutrition into stomach has been suggested because it has contributed substantially to the reduction in frequency of stress ulcer-related bleeding that has been observed over the past 30 years. In critically ill patients, sustained enteral nutrition has been shown to be more effective at raising intragastric $\mathrm{pH}$ than $\mathrm{H} 2 \mathrm{RB}$ and PPIs; and enteral nutrition provides better protection against stress ulceration than intravenous H2RB. ${ }^{12}$

Liquid nutrition helps in the prevention of stress ulcers, acts as a buffer for gastric acid, increases mucosal blood flow, increases prostaglandin and mucus secretion. ${ }^{4,18}$ Bonten et al also found that sustained enteral nutrition was more effective at increasing intragastric $\mathrm{pH}$ than PPIs and H2RB. ${ }^{5,18}$ 
Early enteral nutrition has been shown to be effective in preventing stress ulceration of the upper gastrointestinal tract in critically ill patients, especially in burn patients. Intragastric administration of enteral nutrition has a variable effect on gastric $\mathrm{pH}$, improves gastrointestinal regional blood flow distribution, and may decrease intramucosal $\mathrm{pH}$. Feeding has been shown to reduce the effectiveness of sucralfate, whereas co-administration of enteral nutrition and ranitidine for stress ulcer prophylaxis has been associated with reduced bleeding rates. ${ }^{6}$

\section{ASSOCIATED RISK}

An intragastric $\mathrm{pH}$ less than 4 optimal for bactericidal action, gastric acid plays an important role in the natural defense of the stomach. Suppression of gastric acid production and increasing intragastric $\mathrm{pH}$ above this bactericidal threshold carries a risk of increased gastric colonization with pathogenic organisms. ${ }^{12}$ The use of acid-suppressing therapy for SUP allows an increase in gastric $\mathrm{pH}$ and overgrowth of bacteria in the gastrointestinal tract which can lead to infection. ${ }^{15}$ Studies show that PPI therapy may be associated with an increased risk of hospital-acquired pneumonia. The mechanisms include an increase in gastric $\mathrm{pH}$ which promotes the growth of bacteria in the stomach (especially gram-negative duodenal bacilli) by esophageal reflux and aspiration of gastric contents leading to airway colonization or pneumonia. ${ }^{1}$

A mechanism that has been suggested to contribute to infection related ventilator associated complications (IVAC) is contamination of the oropharynx by reflux of gastric fluid, with aspiration of oropharyngeal bacteria into the lower airways. Since many organisms cannot live in an acidic environment, administration of drugs that increase the $\mathrm{pH}$ of the stomach can facilitate colonization of the stomach with pathogenic organisms and predispose to respiratory infections. ${ }^{12}$

Infection with $C$. difficile is relatively common in mechanically ventilated critically ill patients. Using data from more than 65,000 patients in the United States requiring prolonged mechanical ventilation, C. difficile-related diseases were found in more than $5 \%$ of patients. In addition, C. difficile infection was important because it led to substantial increase in length of stay (6.1 days; $95 \%$ CI: 4.9-7.4). In a prospective case-control study of 303 patients admitted to a general medical ward, Yearsley et al reported a two-fold increase in association with $C$. difficile disease in patients receiving PPIs. ${ }^{12}$
Investigators identified two independent predictors of $C$. difficile infection: long duration exposure to proton pump inhibitors $(\mathrm{OR}=2.0 ; 95 \% \mathrm{CI}: 1.2$ to 3.4$)$ and use of antimicrobial agents $(\mathrm{OR}=2.5 ; 95 \% \mathrm{CI}$ : 1.2 5.2). ${ }^{5}$ Antibiotic use is the most important risk factor for $C$. difficile infection in intensive care patients. ${ }^{18}$

\section{Prophylaxis Termination}

Many physicians continue stress ulcer prophylaxis until the patient starts or is on an oral diet or is transferred from intensive care ward to the normal ward. Most experts consider the risk of clinically significant bleeding outside the intensive care setting too low to justify continuing prophylaxis. Treatment algorithms or protocols for stress ulcers based on prescription patterns, hospital formularies, and cost analysis should be considered for each institution to guide critical care clinicians about appropriate use of stress ulcer therapy. ${ }^{6}$

It is unclear when prophylaxis should be stopped. Although it has been recommended that prophylaxis continued for at least 7 days. Most of studies recommend continuation of stress ulcer prophylaxis during critical illness or stay in an intensive care unit. ${ }^{22}$ Regular re-evaluation of individual indications for using SUP during and after stay in the intensive care unit is mandatory. ${ }^{9}$

\section{CONCLUSION}

Clinically significant stress ulcer bleeding is rare in patients without risk factors, routine stress ulcer prophylaxis may not be cost effective and should probably avoided in this subgroup. Admission to hospital or intensive care unit alone is not sufficient reason to provide prophylaxis. Mechanical ventilation for more than 48 hours and coagulopathy are the major risk factors for stress-induced upper gastrointestinal bleeding.

Critically ill patients often develop gastrointestinal lesions due to altered gastric mucosal perfusion, reduced mucosal protective factors and increased gastric acid, putting them at risk for gastrointestinal bleeding due to SRMD or ulcers. PPI agents have been recommended for use as first-line therapy because of their high efficacy. However, routine use of stress ulcer prophylaxis in all critically ill patients may be dangerous and does not appear to be cost-effective. SUP administration must follow an algorithm that clearly balances risks and benefits. Alternative strategies such as enteral nutrition or limiting SUP in the early phases 
of treatment in the intensive care room for high-risk patients. Utilizing SUP checklists and criteria reduces unnecessary SUP drug administration.

\section{REFERENCES}

1. Alhazzani W, Alshahrani M, Moayyedi P, Jaeschke. Stress ulcer prophylaxis in critically ill patients: review of the evidence. Department of Critical Care and Emergency Medicine, King Fahad Hospital, Dammam University. Saudi Arabia 2012;122:107-14.

2. Bardou M, Quenot JP, Barkun A. Stress-related mucosal disease in the critically ill patient. Gastroenterology and Hepatology Department and Medical Intensive Care Unit CHU De Dijon. France. Nat Rev Gastroenterol Hepatol 2015;12:98-107.

3. Fennerty MB. Pathophysiology of the upper gastrointestinal tract in the critically ill patient: Rational for the therapeutic benefits of acid suppression. Crit Care Med 2002;30:S351-55.

4. Reyes JMA, Ramirez HJ. Prophylaxis for stress ulcer bleeding in the intensive care unit. Rev Gastroenterol Mex 2014;79:50-5.

5. Cook D, Guyatt G. Prophylaxis Against Upper Gastrointestinal Bleeding in Hospitalized Patients. N Engl J Med 2018;378:2506-16.

6. Ali T, Harty RF. Stress-Induced Ulcer Bleeding in Critically Ill Patients. Section of Digestive Disease and Nutrition, Department of Internal Medicine, University of Oklahoma Health Science Center. United States 2009.p.245-65.

7. Rwashdeh N. Stress Ulcer Prophylaxis (SUP) Guideline. Drug Information Center. King Abduazzis University. Saudi Arabia. 2011.

8. Eisa N, Bazerbachi F, Alraiyes AH, Alraies MC. Do all hospitalized patients need stress ulcer prophylaxis?. Cleve Clin J Med 2014;81:23-5.

9. Buendgens L, Koch A, Tacke F. Prevention of stress-related ulcer bleeding at the intensive care unit: risk and benefits of stress ulcer prophylaxis. World J Crit Care Med 2016;5:57-64.

10. Chia CTW, Lim WP, Vu CKF. Inappropriate use of proton pump inhibitors in a local setting. Singapore Med J 2014;55:363-6.

11. Ogasawara O, Kojima T, Miyazu M, Sobue K. Impact of the stress ulcer prophylactic protocol on reducing the unnecessary administration of stress ulcer medications and gastrointestinal bleeding: a single-center, retrospective pre-post study. J Intensive Care 2020;8:10.

12. Plummer MP, Blaser AR, Deane AM. Stress ulceration: prevalence, pathology and association with adverse outcomes. Discipline of Acute Care Medicine, University of Adelaide. Australia 2014;18:213.

13. Sesler J. Stress-related mucosal disease in the intensive care unit. AACN Adv Crit Care 2007;18:119-28.

14. Setiati S, Alwi I, Sudoyo AW, Simadibrata M, Setyohadi B, Syam AF. Pengelolaan Perdarahan Saluran Cerna Bagian Atas. Buku Ajar Ilmu Penyakit Dalam. $6^{\text {th }}$ eds. Interna Publishing:Jakarta 2014.p.1875-82.

15. Viesselmann C, Kinney G, Fish J, Willenborg N. Stress Ulcer Prophylaxis in the Intensive Care Unit-Adult/ Pediatric/ Neonatal - Inpatient Clinical Practice Guideline. University of Wisconsin Hospitals and Clinics. United States. 2017.

16. Hutchinson S. Join Trust Guideline for the Use of Stress Ulcer Prophylaxis in Adult Critically Ill Patients. England 2020.
17. Waldum HL, Kleveland PM, Fossmark R. Upper Gastrointestinal physiology and diseases. Department of Gastroenterology and Hepatology. Norwegian University of Science and Technology. Scand J Gastroenterol 2015;50:64956.

18. Alghamdi, Allah MY, Alluhaybi AH, Alzahid AA, Akkur MA, Alshenaiber MAA, et al. Evaluation of stress ulcer prophylaxis benefits and outcomes: a simple literature review. The Egyption Journal of Hospital Medicine 2018;72:5444-9.

19. Friedman SL, Mcquaid KR, Grendell JH. Peptic Ulcer. Disease. Current Diagnosis \& Treatment in Gastroenterology. Mc Graw Hill Education. United States 2003.p.324-40.

20. Kasper DL, Hauser SL, Jameson JL, Fauci AS, Longo DL, Loscalzo J. Approach to the Patient with Critical Illness. Harrison's Principles of Internal Medicine. Mc Graw Hill Education. United States 2015.p.1729-35.

21. Feldman M, Friedman LS, Brandt LJ. Gastrointestinal Bleeding. Sleisenger and Fordtran's Gastrointestinal and Liver Disease $10^{\text {th }}$ ed. Elsevier Saunders: Philadelphia 2015.p.297-35.

22. Guillamondegui OD, Gunter OL, Bonadies JA, Coates JE, Kurek SJ, Moya MAD, et al. Practice Management Guidelines for Stress Ulcer Prophylaxis. Eastern Association for Surgery of Trauma. United States. 2008. 